anterior muscle showed on histological examination extensive "vacuolar myopathy." Three months after stopping chloroquine the patient recovered the use of her legs; a second muscle biopsy showed an increased number of intact muscle fibres and almost complete disappearance of myopathic vacuoles. Unfortunately, owing to extensive damage of her retina by chloroquine, she obtained only slight visual improvement.

Detectable amounts of chloroquine have been found in urine, red blood cells, and plasma of patients with chloroquine retinopathy for as long as five years after stopping the drug, ${ }^{2}$ and in experimental animals, such as albino rats, chloroquine was found to be present in the retina 14 months after stopping the administration of the drug. ${ }^{3}$ In a large series of patients with rheumatoid arthritis treated with low doses of chloroquine for one to nine years, $10 \%$ of patients were found to develop characteristic chloroquine corneal deposits. ${ }^{4}$

Thus the use of even small doses of chloroquine for long periods of time cannot be recommended with confidence.-I am, etc.,

Department of Immunology,

Middlesex Hospital Medical School,

London $\mathrm{W} .1$

1 Ebringer, A., and Colville, P., British Medical Fournal, 1967, 2, 219.

2 Rubin, M., Bernstein, H. N., and Zvaifler, N. J., Bernstein, H. N., Zvaifler, N. J., Rubin, M., and
Mansour, A., Investigative Ophthalmolo;y, 1963, 2, 384 .

4 Scherbel, A. L., Mackenzie, A. H., Nousek, J. E.,
and Atdian, M. New England fournal of Medicine, 1965, 273, 360 .

\section{Mutants, Hyperlipoproteinaemia, and Coronary Artery Disease}

SIR,-The paper by Dr. D. S. Fredrickson (24 April, p. 187) with comments on the recommendations of the Atherosclerosis Study Group ${ }^{1}$ acts as an invitation to give a few additional remarks on the subject from a practical point of view. For dietary measures on large scale-for example, prescribing the amount and kind of fat in the diet, it must be realized that the number of individuals with a carbohydrate-induced hyperlipidaemia and/or decreased glucose tolerance and/or too high insulin production can be fairly high and percentages up to 30 , 15 , and $30^{\circ}$ of adult individuals of the respective population groups under study have been reported. 23 About the genetic factors no information is available and these cases might not be types IV hyperlipoproteinaemia as defined by Dr. Fredrickson. Nevertheless, a low-fat high-carbohydrate diet does not seem the measure of choice for the hyperlipidaemia of these subjects.

Since there is evidence that the decreasing effects on the serum lipid levels of fats rich in polyunsaturates is larger in high-fat (35$50 \mathrm{Cal} \%)$ than in low-fat $(20 \mathrm{Cal} \%)$ diets there is no need for fat restrictions (to less than $35 \mathrm{Cal} \%$ ) if the total amount of the polyunsaturates is about $40 \%$ of total fatty acids, even for fat-induced hyperlipidaemias in males, ${ }^{4}$ and even apart from the fact that hardly anyone is aware of his dietary composition in $\mathrm{Cal} \%$, and therefore changing it is a haphazard procedure.

This would mean that stopping of smoking, increasing (not uncontrolled for adults) or maintaining physical activity to a total energy expenditure of twice the B.M.R.resulting in low serum lipid levels irrespective of the dietary composition (under Dutch conditions), ${ }^{5}$ which will also counteract obesity-are measures suitable for all individuals. The same applies to the appropriate increase of the polyunsaturated fat content of the daily food by taking the special brands of margarine ( $>50 \%$ PUFA) and edible oils which are on the market.

Only biochemical measurements-preferably by automated central laboratories producing data on a nationally and internationally standardized way-can provide the information for a more detailed dietary adjustment whether or not it is complemented by drugs normalizing hyperlipidaemia, hypertension, low fibrinolytic, and/or high clotting activity, etc.-I am, etc.,

Amsterdam, Holland

L. M. Dalderup

1 Atherosclerosis Study Group, Circulation, 1970, 42, A55.

2 Dalderup, L. M., Netherlands fournal of Nutrition, in press.

3 Iamarino, R. M., Communication no. 87 at the XIX Colloquium of the Protides of the BioBruges, April 1971.

4 Vergroesen, A. J., de Boer J., and Thomasson, $\mathrm{H}$. J., in Proceedings of the 2nd International Symposium on Atherosclerosis, Chicago, ed.
R. J. Jones p. 452 . New York, Springer, 1969. Dalderup, L. M., et al. Netherlands fournal of Nutrition, 1971, 32, 41 .

\section{Pathogenesis of Myasthenia Gravis}

SIR,-May I refer to your leading article on "Pathogenesis of Myasthenia Gravis" (3 April, p. 1). There are three reports of sarcoidosis with myasthenia gravis to be found in the literature. ${ }^{1-3}$ This supports my suggestion (1 May, p. 275) that the myasthenia syndrome is sometimes caused by sarcoid inflammation. Two cases had atypical hyperthyroidism, and the weakness in both was improved by prednisone treatment. Sarcoidosis is relatively common, but the subacute inflammation is often silent and anyhow covers its traces soon. Earlier biopsies and Kveim tests are needed to diagnose more cases. For instance, another example of "sarcoid hyperthyroidism" recently in a 10-year-old girl with granulomas in the gland. ${ }^{-}-\mathrm{I}$ am, etc.,

G. A. MACGREgor

Chilworth, Surrey

1 Javitt, N. B., and Daniels, R. A., Fournal of the Mount Sanai Hospital, 1959, 26, 177

2 Simpson, J. A., Fournal of Neurology, Neurosurgery and Psychiatry, 1964, 27, 485.

3 Riehl, J. L., and Hanley, J., Bulletin of the Los $1966,31,100$. Karlish, A. J., and MacGregor, G. A., Lancet, 1970, 2, 330 .

5 Hemmings, I. L., and McClean, D. C., fournal of Pediatrics, 1971, 78, 131 .

\section{Accident and Emergency Services}

SIR,-The decision of the Central Committee for Hospital Medical Services to propose a career structure in accident and emergency work (Supplement, 19 December, p. 65), and the timely and influential advocacy of $m y$ orthopaedic friend John Charnley (1 May, p. 279) signal what I hope will soon be the end of the weary journey towards the establishment of services directed undividedly to- wards the injured. I was very heartened to see that Mr. F. C. Durbin (15 May, p. 400) also believes that casualty departments must be staffed by men making this work a permanent career. I had thought that we might be in disagreement when he took me to task in his earlier letter (16 January, p. 177), saying that $I$ envisaged a traumatologist as a general surgeon with no real expertise. But he misunderstood me. I envisage a traumatologist as a broadly based surgeon with general rather than orthopaedic (or, say, neurosurgical) expertise in the management of the whole injured patient. I cannot see such a man as the "narrow traumatologist" (surely a contradiction in terms?) mentioned by Dr. C. S. Flowers (20 February, p. 462). Specialization is at present badly in need of some counter trend, and traumatology, the original form of general surgery, would provide this nicely.

Neither Mr. M. Ellis nor I (26 December, p. 800) suggested that a single consultant in attendance from 9 a.m. until 5 p.m. would solve a casualty department's problems, though Mr. Ellis indicated that even this might be better in many respects than if the department were under the care of an orthopaedic department whose interest in trauma was not its primary one. Indeed, Mr. M. A. Nelson's and Mr. F. F. Silk's (27 February, p. 506) unwillingness to allow "accident and emergency" even the status of a department has been the common ivorytower view from teaching hospitals, which believe that, because all specialties are available, trauma should not be a specialty. This error ignores the needs of those nonteaching hospitals which have to deal with nearly all the nation's trauma, but without either a full range of specialists or men trained comprehensively enough to deal with all types of injury.

The argument over semantics is unimportant except that it is usually better to mean what one says. "Traumatologist" is an ugly word, but it does describe accurately what is needed and what is the man's primary interest. "Accident Surgeon" would do as well. Indeed, some orthopaedic surgeons might welcome the opportunity offered by this reorientation of their work to describe themselves more accurately-unless of course their primary interest and work were the straightening of children. This debate will also be less confused if trauma can be distinguished from non-traumatic emergencies. A good man, well trained to deal with accidental injury, will usually be able to cope adequately with most emergencies but, as Messrs. Nelson and Silk say, he should not normally be expected to have the additional responsibility for cases which properly belong to other specialists on the staff of the same hospital.

Lack of money and staff continue to be blamed, but I still believe that these are secondary deficiencies. Why give money to combat it if trauma is not a subject and doesn't deserve even a department? And why-except to fulfil examination requirements of the Royal College of Surgeonsgo in for work in which there is no career? At last, it looks as if the correct diagnosis is being reached in this difficult and chronic case.-I am, etc.,

JOHN M. POTTER

Department of Neurological Surgery, Department of Neurol
Oxforfe Infirmary,
Oxford 